\title{
Biodiversity, Historic Importance and Threats of Garanduwa Lagoon Situated in Mirissa Tourist Zone: A Case Study
}

\author{
D. Senaratna ${ }^{1 *}$, M.M.K. Premakumara ${ }^{1}$, U. Gamage ${ }^{2}$ \\ ${ }^{1}$ Department of Animal Science, University of Ruhuna, Sri Lanka \\ ${ }^{2}$ Eco-Lagoon Safari, Mirissa North, Mirissa \\ *dulcy@ansci.ruh.ac.lk
}

\begin{abstract}
Out of 89 lagoons, Garanduwa is the only lagoon located nearly $3 \mathrm{~km}$ away from the sea that comes under atoll lagoon. The extent is approximately $65 \mathrm{~km}^{2}$. It is located in association with unexplored southern coast and belongs to five Gramaseva divisions; Udupila, Thanhagoda, Garanduwa, Henwala, and Thalaramba in Matara district. It is intermittently connected to ocean by two restricted inlets; Mirissa, Udupila and Thalaramba. A case study was conducted to investigate the biodiversity, historic background and the threats in association with the tourist industry. A reconnaissance survey was carried out in the morning and evening by a catamaran boat to identify fauna and flora. Thirty five villages were interviewed by a questionnaire to gather information on the history and prevailing threats. Garanduwa lagoon hosts rich assemblages of different species. Variation of muddy and sandy sediments is home to a rich biodiversity. Different variety of trees, many insects, reptiles, amphibians, birds, mammals thrive in the habitat. More than 20 bird species were recorded. Wooly-necked storks, Indian pond heron, Ceylon blue magpies, common babler, Ceylon hill mynah, crimpson backed wood peckers, little egret, larger egret, spot billed pelican, Ceylon green pigeon, purple coot, black robin, Southern common babler, scimitors, paradise fly catchers, orioles, chaffinchs and bats were prominent. Breadfruit and its wild species, Kirala, Kadol, Jak fruit, Cashew nut, Hog plum, Grosse sapota, Kekuna, Bael fruit were the prominent tree species. Variety of crab species were found among the roots, on the trunks and within the canopy. The name "Garanduwa" derived from a Sanscrit term because of the presence of many crocodiles in the past. At present crocodiles became extinct. Ancient prince named "Keerthi" ( $10^{\text {th }}$ century), later became as the King 1 Wijayabahu built his palace in the island within the lagoon. The king was adorned with the sword to the battle against Solli at the palace was called as "Siribandala Palace" and still the ruins are remaining. Because of close proximity to many tourist hotels, there is a potential to build tourist hotels by destructing the nature and will be a potential site for sewage accumulation. Therefore, it is timely important to save this wetland for a sustainable utilization and thereby encourage ecotourism.
\end{abstract}

Keywords: Atoll lagoon, Biodiversity, Garanduwa, History, Threats 